ISSN: 0213-2079

DOI: http://dx.doi.org/10.14201/shhmo201335237269

\title{
GUERRA, VENALIDAD Y ASIENTOS DE SOLDADOS EN EL SIGLO XVIII*
}

\section{War, Venality and Soldier Contracts in the XVIII Century}

Francisco ANDÚJAR CASTILLO

Universidad de Almería

Correo-e: fandujar@ual.es

RESUMEN: Durante el siglo XVIII cada vez que la monarquía hispánica necesitó nuevos cuerpos de ejército para la guerra recurrió al sistema de levas privadas, porque era el que proporcionaba al rey soldados con mayor eficacia, en el menor tiempo posible y a más bajo coste. La contrapartida siempre fue la entrega a los asentistas o levantadores de regimientos de las patentes en blanco para que nombraran en los empleos de la oficialidad a quienes les entregasen una determinada cantidad de dinero o su equivalente en hombres reclutados. En el presente estudio se procede a un análisis de la evolución histórica de los asientos para la formación de regimientos, se revisa el concepto de asiento para darle un sentido más amplio del que la historiografía le ha otorgado hasta ahora, se analizan las distintas tipologías de contratos en función del tamaño de las unidades a levantar, se estudia la cronología de los asientos a lo largo de todo el siglo y, por último, se presenta un modelo de formación de un regimiento para mostrar los dos factores esenciales, riqueza y experiencia previa, que confluyeron en quienes se aventuraron a levantar nuevas unidades militares. Finalmente, se aborda el estudio de la venalidad de los empleos de la oficialidad que comportaba la formación de regimientos.

Palabras clave: venalidad, siglo XVIII, contratos, soldados, reclutamiento militar.

El presente estudio se ha realizado en el marco del Proyecto de Investigación de I+D El poder del dinero. Dimensiones de la venalidad en los siglos XVII y XVIII (HAR2011-23105) financiado por el Ministerio de Economía y Competitividad. 
ABSTRACT: During the XVIII century, every time the Hispanic monarchy was in need of new military units for war, they resorted to the private levy system, since this was the most effective, fastest and cheapest system to provide the king with soldiers. The compensation always consisted in the granting of blank patents to the army contractors or troop raisers for them to appoint military positions to those who provided a certain amount of money or its equivalent in recruited men. This study analyzes the historical evolution of contracts for the raising of armies, revises the concept of contract to grant it a meaning wider than the one given by historiography to date, analyzes the different types of contracts according to the size of the armies to be raised, studies the chronology of contracts throughout the entire century and, lastly, presents a model of troop raising to illustrate the two key elements that converged in those who ventured to raise new military units: wealth and previous experience. Finally, this survey addresses the study of the venality of military positions which entailed the raising of troops.

Key words: Venality, xviII Century, Contracts, Soldiers, Military Recruitment.

\section{Consideraciones introductorias}

No hace muchos años que en las páginas de esta misma revista dábamos a conocer un estudio sobre uno de los métodos de reclutamiento más desconocidos hasta entonces en la historia de la España Moderna: los asientos para el suministro de soldados a los ejércitos ${ }^{1}$. Apenas transcurrida una década desde aquella aportación, por fortuna, el panorama historiográfico ha cambiado tanto que hoy es posible no solo revisar lo expuesto en su día sino también plantear nuevas reflexiones y elementos de debate. Justo un año después de esa aportación, aun sin ser el objetivo central del estudio, añadimos una nueva perspectiva sobre el reclutamiento de soldados en el siglo XviI al demostrar la importancia que tuvo la formación de nuevos cuerpos de ejército y su vinculación con la venalidad de los empleos de la oficialidad, pues buena parte de los regimientos que se formaron a lo largo de esa centuria se financiaron mediante la venta de las patentes en blanco por parte de los «levantadores» de dichas unidades ${ }^{2}$. Múltiples asientos, ora con particulares, ora

1. Andújar Castillo, F.: «La privatización del reclutamiento en el siglo XVIII: el sistema de asientos», Studia Historica. Historia Moderna, 25 (2003), pp. 123-147.

2. Andújar Castillo, F.: El sonido del dinero. Monarquía, ejército y venalidad en la España del siglo XVIII. Madrid, 2004. 
con militares que aspiraban a ascender, intercambiaron soldados por despachos de oficiales. Tan solo de forma residual la Corona financió la formación de algunos regimientos, o concedió a reinos, provincias y ciudades las siempre deseadas patentes en blanco para que fueran repartidas de forma «gratuita» entre las oligarquías locales que aprobaban la creación de esos cuerpos en sus territorios ${ }^{3}$.

En esa misma línea, pero para una cronología anterior que resulta esencial para entender los elementos de cambio y continuidad entre Austrias y Borbones, los principales avances en la investigación sobre las dinámicas de reclutamiento de soldados se han producido en torno al siglo Xvil y, en su gran mayoría, de la mano de dos jóvenes historiadores, Antonio José Rodríguez Hernández y Antonio Jiménez Estrella. Del primero, su obra, Tambores de Marte, sobre las prácticas de reclutamiento en Castilla en la segunda mitad del siglo $\mathrm{XVII}^{4}$, ha supuesto un revulsivo en los estudios sobre los ejércitos de Carlos II, pero también ha tratado problemáticas específicas tales como las peculiaridades de los procesos de captación de soldados en diferentes espacios de Castilla ${ }^{5}$, las recompensas que la monarquía entregaba a cambio de las reclutas ${ }^{6}$ y las cada vez más escasas contribuciones de la nobleza ${ }^{7}$. Por su parte, Antonio Jiménez Estrella también se ha ocupado del reclutamiento en cronologías anteriores al reinado de Carlos II $^{8} \mathrm{y}$, de forma específica ha abordado el

3. López DíAz, M.a: «Oligarquías urbanas y milicia: apuntes sobre una relación beneficiosa a partir del caso de Ourense (siglo XVIII)», Cuadernos de historia moderna, 34 (2009), pp. 95-123.

4. Rodríguez Hernández, A. J.: Los Tambores de Marte. El Reclutamiento en Castilla durante la segunda mitad del siglo XVII (1648-1700). Valladolid, 2011.

5. Rodríguez Hernández, A. J.: «De Galicia a Flandes: reclutamientos y servicio de soldados gallegos en el ejército de Flandes (1648-1700)», Obradoiro de historia moderna, 16 (2007), pp. 213-251; «La contribución militar del Reino de Granada durante la segunda mitad del siglo XvII: la formación de Tercios de Granada» en Jiménez Estrella, A. y Andújar Castillo, F. (eds.): Los nervios de la guerra. Estudios sociales sobre el ejército de la Monarquía Hispánica (Siglos XVI-XVIII): nuevas perspectivas. Granada, 2007, pp. 149-189; «Factores para un reclutamiento a larga distancia: las levas canarias a Flandes y otros destinos a lo largo de la segunda mitad del siglo XVII", Revista de historia canaria, 189 (2007), pp. 103-132; «Poner una pica vallisoletana en Flandes: reclutamiento y costes del transporte de tropas a los Paises Bajos (1665-1700), Investigaciones históricas: Época moderna y contemporánea, 28 (2008), pp. 55-78.

6. Rodríguez Hernández, A. J.: «Patentes por soldados. Reclutamiento y venalidad en el ejército durante la segunda mitad del siglo XvII», Chronica Nova, 33 (2007), pp. 37-56; «Servir al rey con hombres. Recompensas concedidas a élites y representantes del rey por su colaboración en el reclutamiento (1613-1700)», en Esteban Estríngana, A. (ed.): Servir al rey en la Monarquía de los Austrias: Medios, fines y logros del servicio al soberano en los siglos XVI y XVII. Madrid, 2012, pp. 415-443.

7. Rodríguez Hernández, A. J.: «Los servicios de la nobleza y el reclutamiento señorial en Andalucía durante la segunda mitad del siglo xvil», en Andújar Castillo, F. y Díaz López, J. P. (eds.): Los señoríos en la Andalucía Moderna. El Marquesado de los Vélez. Almería, 2007, pp. 639-654.

8. Jiménez Estrella, A.: «El reclutamiento en la primera mitad del siglo XVII y sus posibilidades venales», en Andújar CAstillo, F. y Felices de la Fuente, M. ${ }^{a}$ M. (eds.): El poder del dinero. Venta de cargos y honores en la España del Antigno Régimen. Madrid, 2011, pp. 169-190. 
mundo de los asientos en el período previo a la guerra de Portugal 9 . Sus aportaciones, no solo complementan las de Rodríguez Hernández, sino que permiten dar plena continuidad a la impagable obra que nos regalara hace años Irving A. Thompson ${ }^{10}$.

Todos esos estudios, así como los trabajos de otros autores, tanto para la misma corona de Castilla ${ }^{11}$ como para la corona de Aragón ${ }^{12}$ u otros territorios de la monarquía ${ }^{13}$, demuestran la enorme diversificación de métodos de reclutamiento que se pusieron en marcha a lo largo del siglo xvir y que fluctuaron en función de las coyunturas económicas y bélicas, y de la capacidad de la monarquía para acometer empresas reclutadoras, tanto en el plano financiero como organizativo. De la multiplicidad de sistemas de recluta y de las extremas necesidades de hombres en que se vio la monarquía en algunas etapas, da buena prueba el caso excepcional del recurso a reclutar compañías de bandoleros ${ }^{14}$.

En líneas generales, se puede afirmar que durante la centuria del Barroco la movilización de hombres para la guerra evolucionó desde la administración directa mediante el sistema de comisión que predominó hasta 1635, hacia los diversos métodos de administración indirecta que se aplicaron a partir de entonces como consecuencia de la crisis del voluntariado. Se desarrollarían, por tanto, una serie de cambios que se plasmarían en la imposición de métodos coercitivos de reclutamiento y, paralelamente, en un mayor peso de los sistemas que Thompson calificó como de «reclutamiento intermediario» y que tuvieron sus pasos más firmes durante el valimiento del conde duque de Olivares. Recursos como el llamamiento a las milicias -luego «compuestas» a dinero para tratar de financiar las reclutas de voluntarios- o los intentos de movilización de la nobleza durante las guerras de Cataluña y Portugal, no obtuvieron los resultados esperados, por lo que hubo que recurrir a intensificar los medios indirectos de captación hombres. En consecuencia, nuevos métodos iban a adquirir un incuestionable protagonismo en el reclutamiento de soldados, al tiempo que se incrementaría la incorporación

9. Jiménez Estrella, A.: «Servir al rey, recibir mercedes: asentistas militares y reclutadores portugueses al servicio de Felipe IV antes de la Guerra de Restauración», STUMPF, R. y ChaturveDULA, N. (eds): Cargos e ofícios nas monarquias ibéricas: provimento, controlo e venalidade (séculos XVII-XVIII). Lisboa, 2012, pp. 239-266.

10. Thompson, I. A. A., Guerra y decadencia. Gobierno y administración en la España de los Austrias, 1560-1620. Barcelona, 1991.

11. Nos exime de abundar en la bibliografía la completa obra de MARTínez Ruiz, E.: Los soldados del Rey. Los ejércitos de la Monarquía Hispánica (1480-1700). Madrid, 2008.

12. Espino López, A.: «El esfuerzo de guerra de la Corona de Aragón durante el reinado de Carlos II, 1665-1700. Los servicios de tropas», en Revista de Historia Moderna. Anales de la Universidad de Alicante, 22 (2004), pp. 209-250.

13. Martínez Arce, M. ${ }^{a}$ D.: Navarra y el ejército en el conflictivo siglo XVII, Pamplona, 2002.

14. Espino López, A.: «Recluta de tropas y bandolerismo durante el reinado de Carlos II: el caso de la compañía ilicitana del capitán Gaspar Irles», Revista de historia moderna: Anales de la Universidad de Alicante, 24 (2006), pp. 487-512. 
de soldados forzosos a los ejércitos sin dejar nunca de lado a los voluntarios que solían aportar hombres de mayor calidad a las tropas. Por tanto, las levas, los repartimientos, los servicios de ciudades, provincias y reinos, la captación de voluntarios, y los asientos, serían los diferentes métodos puestos en práctica por los últimos Austrias para nutrir de hombres sus renombrados Tercios.

La diversificación de los métodos de reclutamiento se prolongó durante el siglo XVIII aunque hubo notables cambios con respecto a la centuria precedente. Ningún método por sí solo podía garantizar el abastecimiento de hombres para el ingente ejército que se forjó durante los años de la Guerra de Sucesión, que mantuvo un nivel considerable de efectivos durante el resto del reinado de Felipe $\mathrm{V}$ y que, en términos cuantitativos, experimentaría un relativo descenso durante la segunda mitad del siglo. Ni las levas de vagos, ni las quintas, ni las reclutas de voluntarios, fueron suficientes para que los efectivos teóricos que debía tener cada unidad militar estuviesen siempre al completo. Es cierto que a partir del reinado de Carlos III hubo intentos de abordar el endémico problema de la falta de efectivos en los regimientos mediante la imposición de mecanismos que permitieran aprontar soldados de forma regular. Sus hitos más relevantes se documentan en la introducción de un sistema de reemplazo anual de hombres desde noviembre de $1770^{15}$, la «quinta» general, sobradamente conocida ${ }^{16}$, y la más ignorada por la historiografía «ordenanza de levas de vagos» de mayo de 1775, que de forma periódica pretendía aportar los hombres que ni las reclutas a cargo de los propios regimientos ni las quintas eran capaces de suministrar. Sin embargo, esos intentos de regular de forma permanente el abastecimiento de los ejércitos mediante quintas y reclutas que se registraron en el reinado de Carlos III no eran nuevos. La única novedad radicaba precisamente en el objetivo de convertir ambos sistemas en operaciones regulares con carácter periódico, pues desde mucho tiempo atrás ambos sistemas funcionaban como mecanismo de abastecimiento de soldados. Basta con señalar el ejemplo de las reclutas de vagos. Según los datos suministrados por Pérez Estévez, entre 1775 y 1782 -período en que se habían regulado las levas anuales- al ejército fueron a parar un total de 3.291 vagos, en tanto que en un mismo período de siete años, contabilizados entre los años de 1730 y 1742, hasta el ejército fluyeron un total de 4.615 vagos, una cifra muy superior a la primera, sin que por entonces estuviese regulada su extracción anual ${ }^{17}$.

15. Puell de la Villa, F.: «La ordenanza del reemplazo anual de 1770», Hispania, 189 (1995), pp. 205-228.

16. La obra que aborda de forma más extensa esta cuestión es la de Borreguero Beltrán, C.: El reclutamiento militar por quintas en la España del siglo XVIII. Orígenes del servicio militar obligatorio. Valladolid, 1989.

17. Pérez Estévez, M. ${ }^{a}$ R.: El problema de los vagos en la España del siglo XVIII. Madrid, 1976, pp. 234-235. 
Ambos modelos, quintas y reclutas, basados en la coerción, respondían a un intento por parte del Estado de tener un mayor protagonismo y control sobre el abastecimiento de soldados a los ejércitos, pero a la postre se acabaría convirtiendo en un fracaso. No obstante, lo que la mayor parte de la historiografía no ha tenido en cuenta es que la imposición de esas quintas y levas trató de ser la alternativa al sistema de reclutamiento que mayor éxito había dado a los ejércitos borbónicos, esto es, la recluta de voluntarios por parte de los propios capitanes, un sistema que fue suprimido en aplicación de las famosas Ordenanzas Militares promulgadas en el año 1768. El cambio fue trascendental pues, mientras que los capitanes estuvieron encargados de lo que las mismas fuentes documentales calificaban como «los intereses de sus compañías», ellos percibían las gratificaciones correspondientes a mantener completas sus unidades y eran los primeros interesados en el buen fin de las reclutas de voluntarios financiadas con cargo a sus propios cuerpos.

El resultado de ese cambio en la política de reclutamiento no se dejó sentir de inmediato pero, apenas transcurrida una década desde su imposición, sería uno de los elementos desencadenantes de la profunda crisis en que vivió el ejército borbónico en las postrimerías del siglo XVIII. Las cifras relativas a la falta de fuerza efectiva en los regimientos de infantería hablan por sí solas. En julio del año 1780 , a los cuerpos de infantería, española y extranjera, les faltaba un $12,5 \%$ para completar el total de soldados que por planta debían tener ${ }^{18}$. Poco más de diez años después, un informe sobre el estado de la infantería remitido por el inspector Félix O’Neille al conde de Campo Alange, Secretario del Despacho de Guerra, cifraba en el 33,37\% la fuerza efectiva que faltaba en los regimientos de su inspección, porcentaje en el que se incluían los cuerpos extranjeros, los tres regimientos irlandeses y el de Flandes ${ }^{19}$.

Por tanto, las mencionadas medidas de ordenación de forma periódica del abastecimiento de soldados al ejército borbónico mediante levas de vagos y quintas, con independencia del éxito que luego acabaran teniendo, podrían ser enmarcadas en el contexto de lo que Thomas Glesener ha denominado como «estatalización del reclutamiento", proceso que observa en su análisis sobre el suministro de soldados para los regimientos extranjeros que servían a la monarquía española en el siglo XviII ${ }^{20}$. Su tesis se fundamenta en que durante la segunda mitad de la centuria se habría producido una mayor implicación del Estado en las tareas de reclutamiento de soldados para los cuerpos extranjeros que se consumaría a partir

18. Archivo General de Simancas [en adelante AGS], Guerra Moderna [en adelante GM], leg. 2915.

19. AGS, GM, leg. 6162.

20. Glesener, T.: «La estatalización del reclutamiento de soldados extranjeros en el siglo XVIII» en Reyes García-Hurtado, M. (coord.): Soldados de la Ilustración: el ejército español en el siglo XVIII. A Coruña, 2012, pp. 237-262. 
de 1769 con la creación de la «recluta general de Flandes», una estructura original financiada en parte por la hacienda real y en parte por los propios oficiales del regimiento de Guardias Walonas de Infantería, cuerpo que, junto con el de Guardias Españolas, era de los de mayor tamaño y prestigio del ejército real. Dicha creación, que permitió suministrar reclutas a los regimientos extranjeros desde el citado regimiento de Guardias Walonas y también a través de la Secretaría de Parma sería, a su juicio, el reflejo de una voluntad política de tener un servicio más eficaz y mejor controlado que permitiría poner fin al sistema de asientos para el suministro de soldados a los cuerpos extranjeros.

Sin embargo, en mi opinión, el debate no radica en «privatización»-referida a los asientos- versus «estatalización» en cuanto a sistemas de reclutamiento, pues se trata de dos formas de aprontar soldados que no guardaban relación entre sí, ya que a la primera se solía recurrir siempre que se creaban nuevos cuerpos o se aumentaba la estructura de los existentes, en tanto que el Estado actuaba como principal agente reclutador de forma permanente para mantener completos los regimientos una vez que esos cuerpos se habían formado y servían de forma regular. Dicho de otro modo, los asientos se utilizarían para la creación de cuerpos, y el Estado se ocuparía luego del abastecimiento de los cuerpos valiéndose de otros medios de recluta. La única excepción a esa dualidad, como hemos señalado, se registraría en los cuerpos de extranjeros que, hasta la imposición de la «recluta general de Flandes», se nutrieron de soldados mediante asientos ${ }^{21}$.

\section{El sistema de Asientos. Revisión de Un CONCEPTO}

De todos esos métodos de recluta, el de «asientos» firmados por la Corona con «intermediarios» para el suministro de soldados nos parece uno de los más importantes, por dos razones. La primera, y principal, porque durante el siglo xviII se impondrá como método esencial para la formación de nuevos cuerpos de ejército. Esta consideración, no bien ponderada por la historiografía, nos permite aseverar que a lo largo de dicha centuria cada vez que se levantaron nuevos regimientos, en una abrumadora mayoría, se pusieron en pie mediante el sistema de asientos, plenamente experimentado en la centuria anterior ${ }^{22}$. Lo demostramos sobradamente cuando tratamos las reclutas que se hicieron en el extranjero para completar las unidades de naciones durante el siglo $\mathrm{XVII}^{23}$. Y del mismo modo constatamos su

21. Andújar Castillo, F.: «La privatización del reclutamiento...», pp. 134-147.

22. Riвот, L.: «Types of Armies: Early Modern Spain» en Contamine, Ph. (coord.): War and competition between States. Oxford, 2000, pp. 37-68.

23. Andújar Castillo, F.: «Empresarios de la guerra y asentistas de soldados en el siglo XVII» en García Hernán, E. y Maffi, D. (eds.): Guerra y sociedad en la Monarquía Hispánica: Política, Estrategia y Cultura en la Europa Moderna (1500-1700). T. II, Madrid, 2006, pp. 375-394. 
extensión cada vez que se levantaron nuevas tropas durante el siglo xviII, desde principio a fin, desde la guerra de Sucesión hasta la guerra contra Francia que se abrió en $1793^{24}$.

La segunda razón de la relevancia del sistema de asientos se encuentra en las implicaciones, en todos los órdenes, que comportaba su aplicación. Tuvo consecuencias en el plano económico por cuanto suponía, grosso modo, una privatización del reclutamiento, una delegación de la tarea en manos de individuos que a cambio obtenían otras compensaciones por la prestación de ese «servicio», a veces de orden monetario - una cuantía de dinero por cada soldado reclutado- y más a menudo en forma de grados de la jerarquía militar que se obtenían a cambio de la entrega de un determinado número de soldados, siempre de acuerdo con las condiciones pactadas. En otras ocasiones esa contraprestación adoptaba la forma de merced honoraria -con frecuencia más valorada en la sociedad del privilegio que los propios cargos de la milicia-, que bien podía ser un título nobiliario o un hábito de las órdenes militares. Recientes estudios han dejado muy claro esos tipo de intercambios por Títulos de Castilla, tanto en la segunda mitad del siglo XVII ${ }^{25}$ como durante los primeros años del reinado de Felipe $\mathrm{V}^{26}$. En cuanto a los hábitos de las órdenes militares su utilización, no ya solo como moneda de cambio, sino como instrumento para «alentar» el reclutamiento de hombres, está plenamente documentada en diversas coyunturas del siglo $\mathrm{XVII}^{27}$.

Pero la necesidad de soldados llegó incluso a que su recluta fuera objeto de intercambio por altos empleos del gobierno de la monarquía. Así, por ejemplo, en septiembre de 1642, Pedro Mesía Tovar, conde de Molina, obtuvo una plaza supernumeraria de consejero de Hacienda y, además, el título de maestre de campo, tras haber cumplido con una leva de 1.000 hombres, con la condición de que transcurridos ocho años de su «servicio» se le daría ejercicio de la misma ${ }^{28}$.

24. Andújar Castillo, F., El sonido del dinero..., op. cit.

25. Rodríguez Hernández, A. J.: «La venta de títulos nobiliarios a través de la financiación de nuevas unidades militares durante el siglo XVII», en AndúJar Castillo, F. y Felices de la Fuente, $\mathrm{M}^{\mathrm{a}}$ M. (eds.): El poder del dinero..., op. cit., pp. 274-300.

26. Felices de la Fuente, M. ${ }^{a}$ M.: La nueva nobleza titulada de España y América en el siglo XVIII (1701-1746). Almería, 2012.

27. Rodríguez Hernández, A. J.: «Servir al rey con hombres. Recompensas concedidas a élites y representantes del rey por su colaboración en el reclutamiento (1630-1700)» en EsTEBAN Estríngana, A. (ed.): Servir al rey en la Monarquía de los Austrias. Medios, fines y logros del servicio al soberano en los siglos XVI y XVII. Madrid, 2012, pp. 415-443; JimÉneZ MorenO, A.: «Honores a cambio de soldados, la concesión de hábitos de las Órdenes Militares en una coyuntura crítica: la Junta de Hábitos (1635-1642)» en Soria Mesa, E. y Delgado Barrado, J. M. (eds.): Las élites en la época moderna: la monarquía española, Economía y poder. T. III, Córdoba, 2009, pp. 155-171.

28. Francisco Olmos, J. M. a de: Los miembros del Consejo de Hacienda en el siglo XVII. Madrid, 1999 , p. 31. 
Muchos años después, Manuel García Bustamante obtuvo igualmente otro puesto de consejero de Hacienda por haber reclutado un Tercio de 1.000 infantes armados de espada que fueron entregados a las autoridades del rey en la ciudad de Cádiz en $1685^{29}$. Incluso, en 1698 se concedieron empleos de gobierno político en América por servicios de reclutas de tropas. En aquel año los gobiernos de Soconusco, Antioquía y Chuchito fueron adquiridos en régimen de futura por Nicolás Rioja Zúñiga, Antonio Alfaro y Antonio José Paredes por sendos servicios para la defensa de Cartagena de Indias de 420, 280 y $275^{30}$ soldados respectivamente, si bien finalmente ninguno de los tres llegó a ejercer los cargos «adquiridos» al verse afectados por el decreto de reforma de 1701 que suprimía todas las enajenaciones de cargos realizadas en los años precedentes ${ }^{31}$. Ya en el siglo XVIII, al margen de los empleos militares adquiridos mediante la entrega de un cierto número de hombres, también se registraron algunos acuerdos como el firmado en 1705 por José Patiño -quien años después iba a ser ministro de Felipe V- por el que conseguía una plaza española en el senado de Milán, también en régimen de futura, por el servicio que se comprometió a hacer de una leva de 500 soldados -aunque finalmente entregó solo 400- para el ejército de Milán que debía entregar vestidos y equipados en Valencia ${ }^{32}$. Y por el mismo camino el marqués de Gabaret consiguió en 1711 el cargo de gobernador de la Aljafería de Zaragoza, tras haber entregado 200 hombres para la guardia de la misma ${ }^{33}$.

En realidad, como se puede apreciar en los ejemplos expuestos, los «contratos» por los que se pactaba la entrega de un título nobiliario, un hábito de las órdenes militares o un cargo de gobierno no eran sino «asientos» fundamentados en unas relaciones contractuales presididas por la venalidad. Conceptuados como «servicios» mediante la entrega de un determinado número de hombres reclutados, no venían a ser sino ventas de honores y cargos $^{34}$. En todos ellos subyacía una negociación previa entre dos partes, la monarquía que necesitaba soldados, y los «levantadores», fuesen estos agentes a título individual, corporaciones municipales o instituciones regnícolas.

29. El cargo le sería luego conmutado por una plaza en el Consejo de Indias en el que debía asistir al marqués de los Vélez, presidente de dicho Consejo y, a la vez, Superintendente de la Real Hacienda. Archivo Histórico Nacional [en adelante AHN], Consejos, Lib. 731.

30. SAnZ TAPIA, A.: ¿ Corrupción o necesidad? La venta de cargos de gobierno americanos bajo Carlos II (1674-1700). Madrid, 2009, pp. 410, 447 y 453.

31. Andújar Castillo, F.: Necesidad y venalidad, España en Indias, 1704-1711. Madrid, 2008, p. 6.

32. AGS, Estado, Lib. 419.

33. AHN, Hacienda, lib. 437.

34. Andújar Castillo, F.: «Venalidad de oficios y honores. Metodología de investigación» en Stumpf, R. y Chaturvedula, N. (eds.): Cargos e ofícios nas monarquias ibéricas..., op. cit., pp. 175-197. 
Por tanto, los denominados «servicios» que durante el siglo XVII hicieron diversas provincias de Castilla, tales como las vascas, Asturias, Cantabria, Galicia, Granada y León, eran en cierto modo una suerte de asientos de características muy similares a los que se firmaban con particulares. Aun manteniendo diferencias específicas en cada una de esas provincias, el modelo respondía a un mismo patrón, pues tenía su origen casi siempre en demandas de la Corona para que las autoridades locales se encargasen del reclutamiento a cambio de recibir como principal remuneración por ese «servicio» las patentes en blanco para el nombramiento de la oficialidad que luego distribuían entre sus clientelas y familias, o bien enajenaban, para sufragar parte de los gastos de las reclutas. En todo caso, aunque esos servicios de soldados se hiciesen a demanda de la Corona, siempre se solían cerrar tras largas negociaciones en las que finalmente se llegaba a un acuerdo o pacto que contenía los mismos elementos que los contratos firmados con «asentistas privados». Aunque el acuerdo no hubiese quedado reflejado en documento alguno, siempre la negociación entre las partes estaba presidida por el intercambio de «bienes». La posibilidad de reclutar más hombres que tenían los intermediarios locales -entendiendo por tales a municipios e instituciones regnícolas-, merced a su condición de "personas de séquito", de gran influencia y poder sobre los grupos sociales inferiores, hizo que fueran el aliado más seguro para la monarquía a la hora de captar más soldados en el menor tiempo posible.

Este sistema de «servicios» de ciudades, provincias y reinos se extendió durante la Guerra de Sucesión con aportaciones decisivas como las de las provincias vascas, Asturias, Galicia, reino de Granada y municipios de la Andalucía occidental, teniendo su final en el año 1718 cuando las Cortes de Navarra aprobaron la formación de un regimiento de infantería que tendría la denominación de «Navarra Nuevo» ${ }^{35}$. En ese momento se pone fin a los «servicios» que tan dilatada trayectoria habían tenido en las provincias vascas ${ }^{36}$, Aragón ${ }^{37}$, Castilla ${ }^{38}$ y Navarra ${ }^{39}$, como mínimo desde el reinado de Felipe III. Desde entonces, cada vez que se formen

35. Ibídem, p. 107.

36. Truchuelo García, S., «El deber de servicio militar al monarca: los casos alavés y guipuzcoano (siglos XVI-XVII)», Iura vasconiae: revista de derecho bistórico y autonómico de Vasconia, 4 (2007), pp. 239-284.

37. Sanz Camañes, P.: Política, hacienda y milicia en el Aragón de los últimos Austrias, 16401680. Zaragoza, 1997; Solano Camón, E.: Poder monárquico y estado pactista (1626-1652). Los aragoneses ante la Unión de Armas. Zaragoza, 1987; Espino López, A., «El esfuerzo de guerra de la Corona de Aragón durante el reinado de Carlos II, 1665-1700», Revista de Historia Moderna. Anales de la Universidad de Alicante, 22 (2004), pp. 209-250.

38. Rodríguez Hernández, A. J.: Los tambores de Marte..., op. cit., pp. 213-282.

39. Colomo García, V.: «Navarra y la defensa de la monarquía en los reinados de Felipe III y Felipe IV (1598-1665)», Príncipe de Viana, 104 (1995), pp. 163-182; Ostolaza Elizondo, M. ${ }^{\text {I I.: }}$ Gobierno y administración de Navarra bajo los Austrias. Siglos XVI-XVIII. Pamplona, 1999. 
cuerpos, la Corona recurrirá al contrato o asiento con particulares, fuesen estos individuos ajenos al ejército o militares que buscaban su ascenso por el «servicio» de reclutar nuevos regimientos.

Como ejemplos de esos «servicios» se pueden citar dos casos en puntos extremos de Castilla. En Galicia, tras duras negociaciones con las Juntas del Reino, una «escritura de asiento», firmada el 30 de julio de $1705^{40}$, puso fin a largas negociaciones mantenidas desde 1702 para la formación de ocho Tercios de infantería que se saldaron con un acuerdo por el que los gastos de armamento correrían con cargo a la hacienda regia mientras que los costes de recluta de soldados, vestuario y manutención serían de cuenta de las Juntas del reino ${ }^{41}$. A cambio, estas últimas, se quedarían con la potestad de nombrar los oficiales de dichos Tercios, o lo que era lo mismo, con la facultad de distribuir -junto con las ciudades- las patentes en blanco, así como de controlar los fondos de los arbitrios para el sostenimiento de dichas unidades ${ }^{42}$. En el otro extremo de la península, en el mismo año de 1705 , Felipe V, a instancias de Jean Orry, aprobó un asiento para que un regimiento de caballería que debía levantar la ciudad de Granada lo formase el hermano de un capitular, Gaspar de Paz, si bien finalmente sería la propia ciudad la encargada de reclutar esa unidad debiendo ocuparse de los gastos de vestuario para recibir a cambio las siempre codiciadas patentes en blanco para el nombramiento de los oficiales ${ }^{43}$.

Por tanto, como se constata en los ejemplos señalados, el concepto de «asiento» estaba plenamente asimilado al de «contrato» entre partes ${ }^{44}$. Por ello, en nuestra opinión, el sentido que solemos dar al término «asiento» debe ser más amplio del que se le ha otorgado hasta ahora pues, por lo general, se ha venido identificando «asiento» con el contrato firmado entre el rey y el particular para el suministro de

40. SaAvedra Vázquez, M. ${ }^{a}$ C.: «Tradición y novedad ante la guerra. Las Juntas del Reino de Galicia en la Guerra de Sucesión», en Bravo Caro, J. J. y Villas Tinoco, S. (eds.), Tradición versus innovación en la España Moderna. T. II, Málaga, 2009, pp. 1142.

41. Andújar Castillo, F.: El sonido del dinero..., op. cit., p. 51.

42. Vid. Eiras Roel, A.: «Las ciudades gallegas ante el cambio dinástico. De las Juntas del Reino seiscentistas a las reformas de Nueva Planta» en Fernández Cortizo, C., Migués Rodríguez, V. M. y Presedo Garazo, A. (eds.): El mundo urbano en el Siglo de la Ilustración. T. I, Santiago de Compostela, 2009, pp. 15-50; SAAvedra VÁzquez, M. ${ }^{a}$ C.: «La elite militar del Reino de Galicia durante la Guerra de Sucesión» en López Díaz, $\mathrm{M}^{\mathrm{a}}$ (ed.): Elites y poder en las monarquías ibéricas. Del siglo XVII al primer liberalismo. Madrid, 2013, pp. 223-244.

43. Andújar Castillo, F.: «Milicia y nobleza. Reformulación de una relación a partir del caso granadino (siglos XVII-XVIII)», en JimÉnez Estrella, A. y Andújar Castillo, F. (eds.): Los nervios de la guerra. Estudios sociales sobre el ejército de la monarquía hispánica (S. XVI-XVIII): nuevas perspectivas. Granada, 2007, p. 273.

44. Otras tipologías de contratos, relacionadas con la enajenación de ventas de cargos, pueden verse en Andújar Castillo, F.: «Los contratos de venta de empleos en la España del Antiguo Régimen», en Andújar Castillo, F. y Felices de la Fuente, M. ${ }^{a}$ M. (eds.): El poder del dinero..., op. cit., pp. 63-82. 
determinado bien -casi siempre para los ejércitos- en los plazos, precios, y condiciones estipuladas por ambas partes. Dicho de otro modo, «asiento» se vincula a «asentista» y se suele entender que tal término define a quien ha negociado con la Corona el suministro de cualquier elemento necesario para el ejército o la marina y, en el caso que nos concierne, concretamente para el suministro de soldados. Por el contrario, cuando el mismo monarca acuerda con un reino o municipio la entrega de un nuevo Tercio o Regimiento, de acuerdo con unas condiciones pactadas de antemano, a menudo negociadas durante largo tiempo, se suele hablar en ese caso simplemente de «servicio» hecho al soberano por sus súbditos. En consecuencia, la reflexión que se derivaría de tal planteamiento sería que el término "asiento» se aplicaría para definir lo acordado entre un individuo y el rey, en tanto que un acuerdo semejante pactado entre el monarca y una ciudad se entendería como un «servicio» hecho por esta última, casi siempre a petición del monarca. Sin embargo, como hemos mostrado, fuese la parte contratante un particular o una institución, los objetos de contrato y negociación eran los mismos. El Diccionario de Autoridades, en su edición de 1770, entre las múltiples acepciones del término «asiento», definía una de ellas como el «contrato u obligación que se hace para proveer de dinero, víveres o géneros a algún exército, provincia, etcétera», y, como derivación de esa definición, consideraba como asentista a quien hacía «contrato con el Rey o con el público para la provisión del exército, presidios, etcétera» ${ }^{45}$. Por tanto, señalaba de forma muy clara la vinculación del «asiento» con el de contrato con la monarquía. Y contratos - a menudo calificados como «capitulaciones»- se firmaban cada vez que el monarca recurría a terceros para el suministro de soldados para sus ejércitos.

\section{Los ASIENTOS. LA GENERALIZACIÓN DEL SISTEMA EN EL SIGLO XVIII}

El estudio que realizamos sobre la venalidad en el ejército borbónico nos permitió observar que desde el año de 1702 en que se levantan los primeros cuerpos para la contienda sucesoria, hasta el año 1793, en que se forman nuevos regimientos para la guerra contra la Convención, la inmensa mayoría de las unidades que se crearon exnovo lo hicieron por el sistema de asientos, entendiendo por tal la acepción extensa que le hemos dado en las páginas precedentes y que incluiría los «servicios» realizados por municipios, provincias y reinos.

El número de asientos se puede precisar en sus cifras fundamentales para toda la centuria, con excepción de los primeros años de la Guerra de Sucesión, momento en que se levantan un ingente número de regimientos ${ }^{46} \mathrm{y}$ en el que a

45. Diccionario de Autoridades. Madrid, 1770, p. 358.

46. El recurso a estas levas privadas alcanza durante la Guerra de Sucesión tal paroxismo que incluso el rey aprobó en julio de 1703 una propuesta del conde de Moyencourt para formar «un 
las ofertas individuales se suman numerosos servicios de municipios en los que la confusión entre cuerpos de milicias y unidades para el ejército regular permite calcular tan solo cifras mínimas, no datos absolutos. Según nuestras estimaciones, con la salvedad antedicha, la monarquía recurrió entre los años de 1702 y 1711 al sistema de asientos para poner en pie en Castilla unos 90 regimientos -con desigual estructura entre cada uno de ellos pero con un predominio de los de 500 hombres-, a los que habría que sumar 160 compañías y 31 de caballería formadas en Flandes en $1701^{47}$, las levantadas en Italia en 1702 y $1703^{48}$ y las que se crearon en los territorios de la Corona de Aragón antes de su incorporación a la causa del archiduque Carlos de Austria. Una segunda oleada de creación de nuevos cuerpos tuvo lugar entre los años de 1718 y 1720 cuando tras desmovilizar buena parte de las unidades levantadas durante la contienda sucesoria, el inicio de la guerra en Cerdeña y Sicilia obligó a levantar cuarenta batallones de infantería, de trece compañías cada uno, seis escuadrones de caballería y cuarenta escuadrones de dragones ${ }^{49}$. Una tercera etapa reclutadora se abrió en los años de 1734 y 1735 con ocasión de la Guerra de Italia, al crearse veinte regimientos, de los cuales dieciocho se formaron mediante los correspondientes asientos en tanto que dos -el de la Reina y el de Coraceros o Real Alemán-fueron erigidos con cargo a la hacienda regia. Y todavía el reinado de Felipe $\mathrm{V}$ conocería una última operación venal en 1742, cuando doce regimientos de infantería fueron ampliados a una estructura de tres batallones.

Tras el paréntesis de la etapa de paz del reinado de Fernando VI, una nueva coyuntura de formación de regimientos - de caballería y dragones- se registró entre los años de 1762 y 1771, con motivo, primero, del inicio de la guerra de Portugal mediante el sistema de «asientos mixtos»-también denominado como de «capitanes proponentes»- y luego, para incrementar la infantería con nuevas unidades -ocho regimientos más algunas compañías sueltas- que sirvieron, entre otras funciones, para suplir las unidades que debían marchar a América como ejército de refuerzo. Finalmente, el último episodio de creación de nuevos cuerpos de ejército se produciría entre los años de 1793 y 1795, cuando se erigieron dieciséis regimientos para hacer frente a la guerra contra la Convención francesa, de los cuales diez de ellos se levantaron, con diferentes modalidades, por el sistema de

regimiento de 1.200 hombres o más» formado por desertores de las tropas francesas de Luis XIV que habían pasado a España en ayuda de Felipe V. AGS, Gracia y Justicia, lib. 20.

47. Glesener, T.: «Venalidad y fidelidad en los Países Bajos durante el reinado de Felipe V», en Andújar Castillo, F. y Felices de la Fuente, M. ${ }^{a}$ M. (eds.): El poder del dinero..., op. cit., p. 199.

48. Andújar Castillo, F.: «Entre la Corte y la guerra. Militares italianos al servicio de España en el siglo XVIII», en Guerra e Pace in etá Moderna. Annali di Storia militare europea, 1 (2008), pp. 105-134.

49. Andújar Castillo, F.: El sonido del dinero..., op. cit., p. 76. 
asientos, en tanto que los seis restantes respondieron a circunstancias particulares pero que distaban del viejo sistema de «servicios» de reinos, provincias y ciudades extinguido por completo desde $1719^{50}$.

Como se puede observar, los asientos se erigen en el principal medio para conseguir un objetivo bien definido: disponer de nuevas tropas, más efectivos, con la mayor rapidez y con el menor coste posible para la hacienda del rey. Parecen suficientes argumentos como para afirmar que el modelo de asientos para el abastecimiento -de pan, cebada, paja, leña, pólvora, munición, etcétera- de los ejércitos del que la monarquía se valió durante buena parte de la centuria tuvo su correlato idéntico en el suministro de nuevas tropas cada vez que se necesitaron con ocasión del inicio de una contienda bélica. Por ende, en nada difería el método de asientos utilizado para la formación de nuevos cuerpos de ejército de los asientos que se formalizaban para la provisión de víveres para las tropas ${ }^{51}$. Además, al igual que ocurriera con el sistema de asientos para el abastecimiento del ejército y de la armada, que se mantuvo durante todo el siglo $\mathrm{xvIII}^{52}$, del mismo modo perduró durante toda la centuria el sistema de asientos cada vez que se formaron nuevos regimientos.

Puesto en una balanza, el binomio «eficacia-bajo coste», a pesar de los inconvenientes que comportaba, en cuanto a la calidad de los cuerpos reclutados y a las consecuencias que la venalidad inherente al sistema tenía para la carrera profesional de los oficiales, ofrecía siempre argumentos a su favor como para que una y otra vez se recurriese al mismo. Pero, en ese marco, casi siempre habría que situar el factor «necesidad» como elemento nodal explicativo del recurso a los asientos, pues estos se solían pactar en momentos en que la monarquía se hallaba acuciada por una guerra y, por ende, por la imperiosa necesidad de disponer de más efectivos en los campos de batalla. Poco importaba la bisoñez de los soldados y de muchos de los oficiales que los mandaban. En todo caso, eso sería un problema

50. Con excepción del Batallón de Infantería Ligera de Valencia, los demás cuerpos que no se levantaron por el sistema de asientos fueron producto de iniciativas regias -el de Húsares o Caballería ligera y la Legión Real de los Pirineos- o bien resultado directo de la proximidad de la guerra a sus territorios, caso del Primer Batallón de Infantería Ligera de Barcelona, de los Voluntarios Cazadores de Montaña y de los Batallones de Voluntarios de Navarra. Cif. en Andújar Castillo, F.: El sonido del dinero..., p. 365.

51. Torres Sánchez, R.: «Cuando las reglas del juego cambian: mercados y privilegio en el abastecimiento del ejército español en el siglo XVIII», Revista de historia moderna, 20 (2002), pp. 487-512.

52. Torres SÁnchez, R.: "Servir al Rey”, más una comisión: el fortalecimiento de los asentistas en la corona española durante la segunda mitad del siglo xviI» en Mestre Sanchís, A., Fernández Albaladejo, P y Giménez López, E. (coords.): Actas de la IV Reunión Científica de la Asociación Española de Historia Moderna (Monarquia, Imperio y pueblos en la España Moderna). Alicante, 1997, pp. 149-168. 
de la estrategia y del mando de las tropas en combate. Ante todo, primaría la efectividad de un método de reclutamiento, el de asientos de soldados, que bien podría ser interpretado como una muestra más de la incapacidad administrativa de la monarquía que se veía obligada, una y otra vez, a recurrir a la esfera privada ${ }^{53}$.

El método era muy simple. Para formar un nuevo regimiento o batallón, fuere quien fuese el levantador, tenía que financiar una serie de costes que la Corona se ahorraba en caso de que hubiese corrido a su cargo semejante tarea. Por lo general el asentista debía hacer frente a los gastos de recluta, búsqueda de soldados y pago de la prima de enganche, vestuario, armamento, manutención mientras durase la recluta, y transporte hasta el lugar de entrega a los agentes del rey de la nueva unidad. Precisaba, por tanto, de una inversión financiera, de la organización de una empresa cuyos beneficios pueden estimarse en la diferencia entre los gastos que debía afrontar y los ingresos que podía obtener de las patentes de la oficialidad que había pactado que el rey le entregaría en blanco para ser vendidas, bien a quien entregase el dinero en efectivo por cada despacho de oficial o bien a quien pagase su equivalente en soldados. Además, el levantador o asentista, obtenía casi siempre para sí un ascenso en el escalafón o, en caso de ser ajeno a la carrera militar, un grado de oficial que incluso podía ser el de coronel de la nueva unidad.

Tal es el esquema básico de lo que se negociaba entre asentista y los delegados del rey para la formación de los nuevos cuerpos. Pero la casuística y los objetos de negociación entre las partes adquirieron tal complejidad que no matizar ese modelo, aunque sea de forma somera, sería caer en una simplificación. Siempre las autoridades regias partían de la plena convicción de que, con independencia de que se quebrantaran las ordenanzas militares -cosa que poco importaba en momentos acuciantes de guerra-, cuantos más oficiales neófitos en la carrera de las armas adquiriesen las patentes en blanco, más dificultades tendría la puesta en marcha de la nueva unidad contratada. De ahí que en los procesos de negociación la monarquía tuviese un decidido interés para que algunos de los empleos de mando recayesen en oficiales de experiencia. En el lado opuesto, los levantadores, cuantas más patentes en blanco tuvieran en sus manos, más beneficios podían tener de su empresa o, al menos, de forma más provechosa podrían amortizar los costes de su inversión. Desde luego, la patente en blanco más ansiada era la de coronel, que siempre se solía reservar el levantador en el momento de formalizar el asiento con el rey. No obstante, en muchos de esos procesos de negociación el rey trataba siempre de reservarse para sí la provisión de un determinado número de empleos de la oficialidad con el fin de situar en los mismos a militares de experiencia que

53. Andújar Castillo, F.: «Los contratos de venta de empleos en la España del Antiguo Régimen» en Andújar Castillo, F. y Felices de la Fuente, M. ${ }^{a}$ M. (eds.): El poder del dinero..., op. cit., p. 81. 
compensaran y, al tiempo, adiestraran, a todos aquellos que de forma súbita se iniciaban en la carrera de las armas desde empleos como los de capitán o coronel. De hecho, puesto que la obtención del empleo de coronel era siempre el objetivo de cualquier asentista, desde la Secretaría de Guerra se trataba de que otros empleos de la plana mayor de los regimientos, tales como el de sargento mayor y ayudante mayor, recayesen en hombres con experiencia que pudieran encargarse de la instrucción y manejo de armas de la nueva unidad que se levantaba.

Otras cuestiones capitales eran el plazo de entrega a las autoridades regias del regimiento o batallón contratado, el territorio concreto en que se iba a realizar la recluta y las patentes en blanco que se adelantarían al levantador para «alentar» dicha recluta. Entregar los soldados en el plazo estipulado en el asiento, como es obvio, fue una de las dificultades más importantes que debieron afrontar los asentistas, por cuanto las expectativas para encontrar los soldados pactados no siempre se vieron satisfechas al encontrarse problemas tales como la competencia con otros reclutadores por el mismo espacio de captación de hombres e incluso con partidas de recluta de otros regimientos veteranos. De hecho, algunos asientos se frustraron por este problema, y de ahí que la corona no quisiese adelantar la entrega de todas las patentes pactadas con los levantadores. Por su parte, estos últimos demandaban el mayor número de patentes para «alentar» el reclutamiento, eufemismo que no encubría otra cosa que cuantas más patentes obrasen en poder del asentista menos inversión precisaría para cumplir con su contrato, pues disponiendo de ellas podía proceder a realizar «subcontratas» con quien le entregase una compañía completa reclutada o un determinado número de hombres. Por último, en cuanto al espacio de recluta, los asentistas trataban de incluirlo en los asientos en régimen de monopolio aunque no siempre fue aceptada tal cláusula porque, como hemos señalado, para la Corona cuantos más levantadores de nuevos cuerpos hubiese, más posibilidad tendría de reunir los efectivos deseados, además de que no podía limitar que las «partidas» de los regimientos viejos pudiesen seguir desarrollando su actividad para completar las bajas producidas en sus unidades.

Como cualquier otro contrato, la firma de un asiento se hacía cuando culminaba una negociación que, por lo general, había dejado atrás toda una serie de ofertas y contraofertas que solían culminar con el «allanamiento» o aceptación del asentista a las condiciones impuestas por la Corona. Sin embargo, cuando las urgencias de la guerra apretaban a la monarquía, las ofertas recibidas para levantar nuevos cuerpos fructificaban sin demasiadas modificaciones porque primaba ante todo la necesidad de efectivos. En este último caso, aunque desde la Secretaría del Despacho de Guerra se revisaban las propuestas, apenas se ponían objeciones, pues lo acuciante era contar con más soldados en el menor tiempo posible.

El proceso descrito comportaba una evidente privatización de las tareas de recluta de soldados para la creación de nuevos cuerpos de ejército, cuya manifestación más 
preclara radicaba en las subcontratas que se abrían a partir del momento en que un levantador contaba con las patentes en blanco que le permitían proceder a negociar con terceros. El asentista podía optar por la venta directa de las patentes para financiar su empresa, o iniciar una cadena de subcontratas o pequeños «asientos» mediante los cuales cada empleo estaba tasado en la entrega de un cierto número de hombres en las condiciones acordadas, que iban desde la simple recluta hasta la entrega de soldados vestidos y armados. En caso de que la subcontrata la firmase con un capitán y este, además de su patente, hubiese adquirido las de teniente y alférez, se podía llegar a una verdadera cascada de «microasientos» entre particulares, de modo que cada uno se comprometía a entregar el número de soldados acordados a cambio de su empleo. La alternativa al sistema descrito era la venta directa por parte del asentista de las patentes en blanco que había recibido del rey para con su producto hacer frente a los gastos de su empresa. En ambos casos, como se puede observar, lo que comportaban estos asientos para la formación de nuevos cuerpos de ejército, era la generalización de la venalidad de los empleos de la oficialidad que, a pesar de los problemas que comportaba por la falta de experiencia de muchos de los que iban a ser nuevos mandos de los regimientos, siempre era compensada por la eficacia, rapidez y bajo coste con que la monarquía conseguía estas unidades para el ejército.

Sobre esas bases, a lo largo del siglo xviII se pueden documentar múltiples variantes del modelo descrito. No obstante, por lo que hace a la formación de nuevos regimientos se pueden establecer unas tipologías de asientos bien definidas en razón al número de hombres contratados para reclutar mediante este sistema que hemos calificado como de «levas privadas».

\section{Tipologías de los asientos de soldados EN El Siglo XViII}

\section{Los «microasientos»: la recluta "a su costa» de compañias}

Heredado de la centuria anterior, durante la Guerra de Sucesión y, en especial, en sus primeros años, se prolonga la aprobación de un sistema que bien podríamos definir como de «microasientos», consistente en la firma de un acuerdo con el rey para la entrega de una compañía reclutada cuyo número de soldados oscilaba en función de que fuese de infantería o caballería. Era lo que se denominaba como «reclutar a costa» una compañía. Se trataba pues de una pequeña empresa en la que un individuo, fuese militar o no, hacía una oferta al rey para reclutar en torno a unos 50 hombres en infantería -aunque algunas proposiciones superaron esa cifra llegando a los 80 o 100 soldados- y en el caso de caballería una cifra inferior -en torno a 35 o 40 hombres-, pues por lo general también debía aprontar los correspondientes caballos para que el ofrecimiento fuese de «soldados montados». 
A cambio, el ofertante o el familiar para quien se hacía la propuesta, recibía un despacho de capitán del arma contratada.

En la práctica era un sistema venal en el que en lugar de entregar una determinada cantidad de dinero se suministraba al ejército unos soldados cuyo coste de recluta, armamento y vestuario sería equivalente al precio de una patente de las que enajenaban quienes levantaban regimientos completos. Se trataba pues de una inversión financiera que reportaría al «pequeño asentista» el sueldo de oficial para toda la vida-como mínimo el adquirido en el momento de cumplir con su contrato-y el honor y prestigio social que comportaba servir al rey en la carrera de las armas. Por tanto, por dicha inversión obtenía rentabilidad económica y social, pues un grado de capitán de los reales ejércitos otorgaba a su titular y a su familia honra e incluso un estatus social asimilado a la condición de hidalgo.

Aunque resulta imposible precisar la importancia que tuvieron estos «microasientos» en el conjunto de las levas privadas durante los primeros años del siglo xviII, una aproximación, referida al año de 1703, nos da prueba de su relevancia. En ese año Felipe $\mathrm{V}$ aprobó la formación de un total de catorce nuevos regimientos -aunque muchos de ellos mantenían aún el nombre de Tercios- de los cuales diez eran levas privadas y cuatro «servicios» de Madrid, Asturias, Valencia y Guipúzcoa. Todas esas unidades se levantaron con una estructura que osciló entre los 400 y 500 soldados, excepto los Tercios de las tres últimas provincias señaladas que lo hicieron sobre un pie de 600 hombres frente a los 500 que reclutó Madrid ${ }^{54}$. En suma, en ese año los asientos y servicios de las provincias aportaron un total aproximado de 6.800 soldados al nuevo ejército que con tanta urgencia precisaba el monarca. Pues bien, tan solo en el primer semestre de ese año - pues la fuente utilizada deja de aportar información sobre esos pequeños asientos a partir del mes de julio- el rey admitió un total de 22 ofertas de «reclutas a costa» de particulares que supusieron un aporte de 1.040 hombres y algo más de 300 caballos $^{55}$.

Tras el final de la contienda sucesoria, el sistema de pequeños asientos perdurará pero no como un contrato entre un particular y el monarca, sino como acuerdo entre los asentistas de regimientos completos e individuos que compraban sus patentes de oficiales, no con dinero en efectivo, sino mediante el suministro de cierto número de hombres. Por tanto, persistirá el modelo de «reclutar a costa» de particulares pero negociado en el ámbito privado que imponía el contrato previo firmado por el rey con un asentista para que este le suministrase una nueva unidad. A modo de ejemplo se puede señalar el caso de Juan Restituto Castro Aguilera, quien llegaría a ser teniente general de los reales ejércitos, el cual consiguió ascender en septiembre de 1709 de cadete de infantería del regimiento de la

54. AGS, Gracia y Justicia [en adelante GJ], libros 18, 19, 20 y 21.

55. Ibídem. 
Armada a capitán de dragones del regimiento de Lusitania por haber levantado a su costa una compañía ${ }^{56}$; o el caso de Ignacio Guazo Torre que ascendió en 1734 desde alférez del regimiento de caballería de Granada hasta capitán del regimiento de dragones de Mérida por haber levantado a su costa una compañía durante la formación de dicha unidad por parte de Luis de Arteaga ${ }^{57}$.

Con posterioridad a 1734 este sistema de pequeños asientos se extingue casi por completo aunque en la práctica pudo perdurar en acuerdos privados realizados por los asentistas para la formación de nuevos regimientos que se levantaron en años posteriores. En todo caso, al formar parte de negociaciones privadas apenas han quedado huellas documentales. No obstante, este sistema de recluta rebrotaría con posterioridad de forma puntual en algunas ocasiones bajo otras fórmulas pero siempre vinculado a la venalidad de los empleos. En concreto, en tiempos de Carlos III, con otras características se volvería a utilizar.

Por último, cabría señalar una etapa en la que algunos grados de capitanes se concedieron por servicios de recluta aunque en muchos casos tales «servicios» fueron utilizados como medio para encubrir compras directas de cargos militares a la hacienanciación de una recluta general se encomendó a un oscuro personaje, José Manuel Vázquez Prego, quien tuvo plena potestad para recibir por parte de los compradores de empleos un determinado número de soldados o su equivalente en dinero ${ }^{58}$. Así, por ejemplo, Adriano Gommelín ascendió de subteniente a capitán del regimiento de Brabante en 1745 por un «servicio» de 35 hombres, aunque desconocemos si finalmente los entregó o si abonó su importe en efectivo ${ }^{59}$. En todo caso, esta práctica permitía situaciones tan rocambolescas como la que sufrió en octubre de 1744 Ignacio Casaleis, un cadete que contrató con Vázquez Prego la entrega, en el plazo de cuatro meses, de cuarenta reclutas a cambio de un despacho de teniente pero que, concluido dicho plazo, solo pudo reunir dieciséis, por lo que obtuvo un puesto de subteniente, si bien perseveró en su intento y en junio de 1745 consiguió su anhelada tenencia, aunque no sabemos si fue merced a haber finalizado la recluta comprometida o a haber entregado su equivalente en dinero ${ }^{60}$.

56. AGS, GM, leg. 2485, C. II.

57. AGS, GM, leg. 2502, C. III.

58. Andújar Castillo, F.: El sonido del dinero..., pp. 185-218.

59. AGS, GM, leg. 5030.

60. AGS, GM, leg. 5032. 
Los asientos medianos (1734-1748)

Siguiendo la misma práctica de intercambio de reclutas por soldados pero comprometiéndose a la leva privada de cuantías superiores de hombres, en los años que transcurren entre 1734 y 1748 se desarrollaron otro tipo de contratos que se pueden situar a caballo entre los mencionados «microasientos» y los contratos para la formación de regimientos.

En el año de 1734, cuando José Patiño -ministro con amplia experiencia venal en su trayectoria personal- estuvo al frente de la Secretaría de Guerra, se formalizaron varias contratas que presentan un particular interés por cuanto supusieron un ensayo previo a la gran almoneda vinculada al reclutamiento que se desarrollará años después entre 1744 y 1748 . El objetivo de esos asientos era completar la falta de efectivos en los cuerpos veteranos, no crear nuevas unidades, y para ello pronto surgieron algunos oficiales del ejército que se erigieron en eventuales «empresarios» que buscaban procurarse un empleo en el escalafón y algunas patentes en blanco con las que financiar sus proyectos de recluta. Los cinco asientos de los que tenemos constancia se acordaron por cuantías que oscilaron entre los 100 hombres que pactó Manuel Perea para ascender de teniente a teniente coronel ${ }^{61}$ y los 300 que se comprometió a entregar Luis Francisco Mayoni por ascender de capitán a coronel ${ }^{62}$. En todos los casos, además de sus propios ascensos, los contratos incluyeron la entrega por parte del rey de una serie de patentes en blanco para que, con su venta particular, pudieran amortizar los costes de la inversión que debían realizar para cumplir con sus «servicios» ${ }^{63}$.

Pero hubo dos contratos cuya resolución final vino a prefigurar lo que acabaría siendo la almoneda de empleos que se enajenaron directamente desde la Corte a partir del año 1744. En concreto, Lope de Mendieta, que era capitán del regimiento de infantería de España, firmó un asiento en 1734 para reclutar, vestir y armar a 250 hombres, a cambio de su ascenso a coronel, más cuatro patentes de capitán y tres de teniente para su venta privada ${ }^{64}$. Sin embargo, el contrato lo iba a cumplir de una forma muy particular pues, en efecto, entregó los hombres pactados pero el importe del vestuario y armamento de los mismos lo abonó en efectivo ${ }^{65}$. Más claro, en cuanto a traducción a dinero del contrato, fue el resultado del asiento que en ese mismo año firmó Francisco Antonio González de la Fuente, alférez del regimiento de caballería del Príncipe, para su ascenso a capitán y percepción del correspondiente sueldo. Su asiento consistió en «costear a sus expensas», o

61. AGS, GM, leg. 2692.

62. AGS, GM, leg. 2692.

63. Andújar Castillo, F.: El sonido del dinero..., op. cit., pp. 135.

64. AGS, GM, Suplemento, leg. 348.

65. AGS, GM, leg. 4253. 
lo que es lo mismo, pagar en dinero, el importe del armamento y recluta de los 120 soldados en que se había visto incrementada la estructura de su regimiento en aquel año de 1734. Negociado a razón de seis pesos por hombre, pues los costes de recluta y armamento eran una mera forma de encubrir un pago directo, le costó el mencionado ascenso la suma de 10.800 reales $^{66}$.

El método ensayado en 1734 iba a tener su pleno desarrollo a partir de 1744 cuando se acometió una amplia operación venal con el fin de financiar una recluta general para completar las bajas causadas en los regimientos veteranos. No se trataba de levantar nuevas unidades sino de conseguir dinero o su equivalente en soldados para supuestamente rellenar las bajas provocadas por las deserciones, las heridas de guerra, los que habían quedado inútiles o habían muerto, y por los retiros de quienes habían cumplido sus años de servicio.

La oferta, realizada directamente desde la Secretaría de Guerra, presentaba como principal novedad la flexibilidad de los asientos. Los aspirantes a un ascenso en el escalafón pactaban que en un determinado plazo entregarían entre 200 y 300 hombres, suma que dependía del grado en el escalafón que poseyeran en el momento de formalizar el asiento y del empleo al que pretendieran ascender. Buena parte de esos asientos, en su mayoría firmados entre 1744 y 1746, tuvieron como protagonistas a capitanes que buscaban ser promovidos al grado de coronel por el «servicio de hombres» que iban a realizar. Pero la gran particularidad de esos asientos radicaba en que si los «oficiales-asentistas» no podían cumplir con lo pactado tenían la posibilidad de entregar en dinero en efectivo el importe correspondiente. Por ello, fuera de los contratos, todo el mundo conocía cuáles eran los precios de mercado. Cada recluta cotizaba en torno a 20 pesos y un ascenso de capitán a coronel costaba, por lo general, unos 300 o 350 hombres, lo cual suponía que quien no pudiera o quisiera acometer la siempre incierta tarea de reclutar soldados podía abonar la cantidad de dinero equivalente que, en el caso expuesto, ascendía a 90.000 reales. Dicha suma fue, por ejemplo, la que abonó en 1746 un capitán de infantería, José Aponte, quien se había comprometido a entregar 300 hombres a cambio del sueldo y grado de coronel ${ }^{67}$. Por su parte, Manuel Téllez Girón, siendo capitán del regimiento de infantería de Cataluña, pagó en 1745 la suma de 105.000 reales, correspondientes a 350 hombres que había ofrecido reclutar en el plazo de cuatro meses, a cambio de que se le diese el sueldo y grado de coronel de los reales ejércitos ${ }^{68}$.

La flexibilidad de los asientos negociados durante estos años era plena pues existía incluso la posibilidad de recurrir a una fórmula mixta, esto es, a la entrega

66. AGS, GM, leg. 1039.

67. AGS, GM, leg. 5055.

68. AGS, GM, leg. 5032. 
de una parte en soldados y otra en dinero. Es lo que hizo, por ejemplo, en 1745 el capitán del regimiento de infantería Julio Deodati, quien tras haber contratado la recluta a su costa de 300 hombres, tan solo pudo reunir la mitad de ellos, por lo que se vio obligado a ingresar en las arcas del rey la suma de 45.000 reales $^{69}$. Otros, por el contrario, lograron reunir los hombres convenidos y se colgaron galones superiores del escalafón por esos servicios de recluta. Fue el caso de José Joaquín Moreno, el cual, siendo teniente coronel del regimiento de Saboya logró su ascenso a coronel tras haber cumplido con la recluta de 200 hombres que entregó a los comisionados regios en la ciudad de Barcelona en $1744^{70}$.

Sea como fuere, este tipo de asientos, amén de las particularidades antedichas, tenían otra de no menor importancia que los hacía muy atractivos para quienes dispusiesen de caudales para invertirlos en su promoción profesional. Aludo a que fuese cual fuese la forma de cumplimiento del contrato que cada uno adoptara finalmente, todos los «oficiales-asentistas» podían recubrir su ascenso de un halo de servicio al rey que alejaba el sonido del dinero de su currículum personal. En las libretas de «vita et moribus» que contenían las hojas de servicios siempre se podría hacer constar, de cara a los demás miembros de la carrera militar, que la promoción profesional directa de un oficial, por ejemplo de capitán a coronel, devenía de un «servicio de hombres» hecho al rey, y que este le había premiado con semejante ascenso.

\section{La deriva hacia la venalidad abierta: los asientos ficticios en tiempos de Carlos III}

La herencia de la confusión entre «servicio de hombres» y venta directa de empleos acabó cuajando en los primeros años del reinado de Carlos III en un nuevo sistema que podríamos denominar como de «asientos ficticios» que sirvieron para financiar los aumentos de efectivos que experimentó el cuerpo de dragones durante los años de 1762 y 1765, y el de caballería en 1762 y 1764, pues desde el inicio de la guerra de Portugal se había visto la necesidad de reforzar dichas armas. Se trataba, por tanto, no de crear nuevas unidades sino de incrementar la estructura de las ya existentes.

En propiedad, no se puede hablar de que fuera un sistema de asientos el empleado para aumentar estos cuerpos sino del uso decidido de esa dinámica de «servir al rey con hombres» -y en este caso también con caballos- que había venido siendo tradicional en el ejército borbónico como instrumento para financiar dicho aumento, utilizando para ello un método claramente venal pero oculto tras esa forma de contribución en especie que suponía la hipotética entrega de

69. AGS, GM, legs. 2729 y 5032.

70. AGS, GM, leg. 3840. 
un determinado número de soldados vestidos, armados y montados a caballo. El método ideado, que denominamos en su día como el de "capitanes proponentes», consistía en que el rey ofertaba un despacho de capitán de caballería o dragones a quien estuviese dispuesto a vestir, armar y montar entre 40 y 50 hombres, y a cambio el proponente recibía un despacho de capitán y dos patentes más, una de teniente y otra de subteniente, para que con su particular venta pudiese financiar ese servicio ${ }^{71}$. La diferencia con lo que había venido siendo práctica habitual consistía en que ahora el rey no adelantaba los despachos en blanco a los capitanes proponentes, sino que cuando estos cumplían con la entrega de los soldados en las condiciones estipuladas o con el pago de su equivalente en efectivo, recibían los pertinentes nombramientos.

En la práctica, la inmensa mayoría de los que actuaron como «capitanes proponentes» no entregaron el servicio comprometido sino que «costearon» su importe a cambio de recibir las mencionadas patentes. A tal efecto, todos conocían muy bien el importe a entregar por su "proposición», pues por entonces un caballo cotizaba a 2.000 reales, el coste de un recluta a 300 y el vestuario, armamento y montura de cada plaza valía en torno a 12.000 reales, de modo que el importe de una compañía se evaluaba en 140.000 reales, de los cuales el capitán proponente enjugaba luego el importe de su venta privada de las patentes de teniente y subteniente. De que aquella práctica no fue sino un artificio urdido para conseguir dinero en efectivo en lugar de entregar hombres y caballos, da buena prueba una orden dictada el 30 de agosto de 1765 por Carlos III prohibiendo que en lo sucesivo los capitanes proponentes entregasen el dinero en efectivo por considerarlo una práctica «contraria a las reales intenciones» ${ }^{72}$. Sin embargo, el Secretario del Despacho de Guerra, a la sazón el marqués de Esquilache, se encargó de que la voluntad regia quedara aparcada porque desde el primer momento en las oficinas de dicho ministerio la operación se había concebido como una venta de empleos, disimulada bajo la forma de asientos, que debía tener como finalidad aprontar la financiación necesaria para que en la práctica el coste de ese aumento de los cuerpos de caballería y dragones fuese acometido por las «partidas» de los propios regimientos con el dinero obtenido de la venta de empleos. En suma, se trataba de costear los aumentos que experimentaron ambas armas entre 1762 y 1766, sin que ello supusiese coste adicional alguno para la real hacienda. Era, sin duda, una deriva final del servicio de recluta de hombres hacia la venalidad abierta que, por otro lado, se venía desarrollando con anterioridad y que se extendería en los años siguientes -hasta 1774- en el arma de infantería, pero ya sin valerse de otro servicio que no fuese el pecuniario de forma abierta.

71. Andújar Castillo, F.: El sonido del dinero..., op. cit., pp. 225-237.

72. Ibidem, p. 234. 


\section{El modelo secular: formación de regimientos y venalidad}

Sin duda, a lo largo del siglo xviII, el modelo más extendido de asiento para el suministro de soldados fue el de la leva privada para la formación de un regimiento completo. Como señalamos, su continuidad durante toda la centuria, cada vez que fue necesario formar nuevos cuerpos de ejército, revela que las características enunciadas de rapidez, eficacia y bajo coste, siempre primaron para que la monarquía acudiese una y otra vez a este medio para levantar nuevos cuerpos de ejército. En las páginas precedentes lo hemos descrito por extenso, amén de que difiere poco de los procedimientos que se utilizaron para erigir otras estructuras militares de menor tamaño, caso de compañías y batallones. Tan solo conviene realizar algunas precisiones.

En primer lugar, señalar que la inmensa mayoría de esos asientos, salvo cuando con cargo a la hacienda real se financiaba alguna parte de la leva, comportaban el desarrollo de una intensa venalidad de los empleos de la oficialidad, pues con el producto de la venta de los mismos era con lo que sufragaban buena parte de los costes del asiento contratado con el rey. Es cierto que muchas patentes de oficiales pudieron obtenerse por vías ajenas a las de un pago monetario, cual sucedió con los servicios que hicieron los reinos, provincias y ciudades durante la contienda sucesoria -que se distribuyeron entre familiares y clientelas de las oligarquías presentes en las instancias de decisión política-, o cuando un asentista distribuía graciosamente dichas patentes entre los que «habían colaborado» en la recluta, o entre sus familiares y allegados. En todo caso, la mayor parte de las patentes de oficiales de los regimientos de nueva leva siempre iban a parar a manos de quienes disponían de los caudales suficientes como para abonar el precio de cada empleo, o de quienes entregaran su importe en soldados.

Pero conviene significar las grandes ventajas que obtenía quien adquiría un empleo en el ejército. Recordemos que mediante la compra de un grado de oficial en una de esas nuevas unidades se podía ingresar en el ejército directamente como alférez, teniente, capitán, teniente coronel o coronel. Del mismo modo, se podían saltar varios grados en el escalafón para quien ya sirviese en la carrera de las armas, e incluso era posible cambiar de arma, casi siempre para buscar la más prestigiosa de caballería. Pero la ventaja más importante de la compra de un empleo-fuese en efectivo, o en «especie» entregando soldados- radicaba en la antigüedad que se conseguía, porque cuando se ingresaba en un empleo en cualquier grado de oficial lo que contaba de cara a la promoción futura era el grado, de tal modo que un individuo que ingresase en la milicia adquiriendo una patente de capitán con fecha, por ejemplo, de 1 de octubre de 1735, tenía más antigüedad para ser promocionado que quien hubiese sido ascendido hasta el grado de capitán con anterioridad a 
esa fecha tras una veintena de años de servicio. De este modo, «beneficiar» ${ }^{73}$ un empleo de oficial no solo garantizaba la percepción del salario del grado adquirido sino la posibilidad de ser promovido en la carrera profesional desde la posición de privilegio que otorgaba antelar a quienes llevaban años luchando en los campos de Marte en espera de un siempre ansiado ascenso en el escalafón. Por tanto, la rentabilidad de la inversión no solo se puede medir en términos de tiempo de amortización del coste de la cantidad pagada por un grado de oficial, sino que habría que sumar la no menos importante rentabilidad social -fundamental en la sociedad del privilegio- y las perspectivas de futuro que se abrían en una carrera en la que con tan solo un día de servicio en el ejército, por ejemplo en el grado de capitán, ya se tenía más antigüedad que cientos de oficiales que servían en ese mismo grado desde largo tiempo y que todos aquellos que llevaban años aspirando al mismo desde los empleos inferiores de alférez y teniente.

Resulta pues de enorme complejidad cualquier análisis que pretenda acercarse a los procesos de levas privadas en términos exclusivamente económicos. Podría hacerse desde la perspectiva del «empresario» o levantador, pero cualquier cálculo sería aproximativo porque aunque pudiésemos conocer los precios de caballos, vestuario y armamento, siempre habría lagunas en cuanto al valor de cada soldado reclutado y, sobre todo, al de la propia patente de coronel que todos los asentistas se solían reservar para sí, amén de que los costes de cada soldado variaban en función de los espacios de recluta y, desde luego, en razón a las subcontratas que cada asentista solía hacer con quienes le suministraban armamento y vestuario y, en el caso de las armas de caballería y dragones, caballos.

Lo que sí queda claro es que el permanente recurso a los asientos para formar nuevos cuerpos de ejército a lo largo de todo el siglo Xviı significó el triunfo absoluto del modelo que Thompson definiera como de «reclutamiento intermediario» ${ }^{74}$, que suponía la privatización de las tareas de recluta y el final de los vínculos tardofeudales de vasallaje mediante los cuales los poderosos reclutaban a «personas de séquito» por su capacidad de influencia sobre todos aquellos que ocupan lugares inferiores en la escala social. Esos vínculos serían sustituidos por los lazos, clientelares, familiares y, desde luego, pecuniarios, que unían a los asentistas con los demás súbditos del rey. Y es que a lo largo de toda la centuria, descontados los servicios de ciudades, provincias y reinos, la totalidad de los asientos fueron

73. Las diferencias entre los conceptos de «beneficio» $\mathrm{y}$ «venta» han sido precisadas recientemente en diversos estudios. De forma monográfica se ha ocupado de ello Felices De LA Fuente, M. ${ }^{a}$ M.: «Venta y beneficio de cargos en la España Moderna: consideraciones en torno al concepto de venalidad» en Stumpf, R. y Chaturvedula, N. (eds.): Cargos e ofícios nas monarquias ibéricas..., op. cit., pp. 199-211.

74. Thompson, I. A. A.: Guerra y decadencia. Gobierno y administración en la España de los Austrias, 1560-1620. Barcelona, 1991, p. 146. 
protagonizados, más que por individuos con capacidad de liderazgo social, por todos aquellos que cumplían dos condiciones: disponibilidad de numerario para la inversión inicial en la formación de una nueva unidad y experiencia previa.

\section{AnÁlisis de un modelo: el Regimiento del marqués de Pozoblanco}

Ambos factores, experiencia y disponibilidad de capitales, fueron determinantes en el ofrecimiento que hizo en abril de 1704 Francisco Manuel de Velasco, marqués de Pozoblanco ${ }^{75}$, para la leva «a su costa» de un regimiento de caballería de doce compañías a razón de treinta hombres cada una ${ }^{76}$. El rey aprobó la oferta pues el levantador, a la sazón ya capitán, pretendía hacerse coronel del nuevo regimiento por el servicio de reclutar las mencionadas compañías, vestirlas, armarlas y costear también los equipajes para los caballos, corriendo de cuenta de la real hacienda el gasto de los caballos. Dicha recluta la haría en Andalucía y Extremadura y se comprometía a tenerla finalizada en el plazo de cinco meses con el compromiso de no admitir a desertores y de entregar el regimiento completo en la plaza de Badajoz para que desde ese momento fuese admitido al «real sueldo». A cambio, el rey le nombraría coronel del regimiento, una vez que su asiento lo cumpliese por entero, y le daría en blanco las patentes de teniente coronel, sargento mayor, diez de capitán, así como las de los demás oficiales de dicho regimiento «para que a su elección los nombre», con la condición de que todos los oficiales que nombrare fuesen «sujetos que hayan servido». Durante el tiempo que durase la leva, el marqués de Pozoblanco seguiría gozando del grado de capitán de caballos y una vez que hubiese entregado el regimiento en Badajoz el rey podría proveer dicha compañía en quien considerase oportuno.

Como se comprueba, estamos ante un asiento en el que el levantador no iba a correr con la totalidad de los gastos de la leva del regimiento y, por ello, en compensación a no afrontar el gasto de los caballos, dos patentes de oficiales quedarían a disposición del rey. Por tanto, el acuerdo trataba de buscar un cierto equilibrio en los costes de financiación del nuevo regimiento para las dos partes contratantes, pues con la venta de las diez compañías más los empleos de la plana mayor el «asentista» preveía amortizar el importe de su inversión. En el ofrecimiento hecho por el marqués de Pozoblanco destaca también otro hecho capital que favoreció que el asiento fuese finalmente aprobado por el rey: el compromiso de que los oficiales que nombrase el levantador tuviesen experiencia militar, aunque

75. El título de marqués de Pozoblanco no guarda relación alguna con la localidad cordobesa sino que procede de una dehesa que con tal denominación poseía Francisco Manuel Velasco en la localidad pacense de Segura de León. De hecho, en 1706 solicitó licencia real para cerrar dicha dehesa. Cif. AHN, Consejos, lib. 2503.

76. AHN, Estado, leg. 804. 
sin especificar el número de años. Y es que precisamente en esta característica de las levas privadas era donde se producían las mayores dificultades para que se aceptasen las propuestas por parte de la Corona, pues siempre el objetivo de los levantadores o asentistas era obtener el mayor número de patentes en blanco para hombres sin experiencia porque de ese modo el valor de venta de cada despacho de oficial era muy superior a la cotización que tenía, por ejemplo, un ascenso de alférez a capitán. Teniendo en cuenta que los cuerpos que se formaban durante esos años de la Guerra de Sucesión iban a entrar de inmediato en combate, era lógico que la nueva unidad que se formaba estuviese integrada por individuos con alguna pericia en el arte de la guerra, circunstancia que no siempre se produjo en todas las unidades creadas durante dicho período.

En la persona del marqués de Pozoblanco concurrían las dos circunstancias necesarias para acometer la empresa de levantar un regimiento de caballería de nueva leva, esto es, disponibilidad de capital y experiencia en la materia. Tenía pues plena capacidad para cumplir con el asiento aprobado por el rey. Por lo que hace a la primera condición es muy escasa la información disponible sobre la familia de de Francisco Manuel de Velasco ${ }^{77}$, aunque todo apunta a que el éxito económico debió llegar a la familia en las postrimerías del siglo xviI. Por entonces, su padre, Juan de Velasco Tejada, que era caballero veinticuatro de Sevilla, consiguió en 1694 un hábito de caballero de Santiago para sí y otro para su hijo Francisco Manuel, valiéndose de la mediación de un agente de negocios residente en Madrid, Francisco de Argandoña, especializado en el tráfico de oficios y honores para ejercer en América ${ }^{78}$. Fue Argandoña el encargado de tramitar la genealogía de la familia y probablemente el que tres años después le agenciaría las relaciones necesarias a Francisco Manuel Velasco para conseguir el título nobiliario de marqués de Pozoblanco ${ }^{79}$. En las referidas pruebas de hábito para caballero de Santiago, Juan de Velasco Tejada figuraba, en efecto, como caballero veinticuatro y como «maestro de campo», pero paradójicamente ninguno de los testigos aludía a su trayectoria que le había permitido llegar hasta ese grado del escalafón militar que nunca desempeñó. Y es que por los lazos de amistad que, con toda certeza, debían unir a solicitante y testigos, estos no podían aludir al origen de ese grado ni a cómo lo había conseguido. Justo dos años antes de pretender el

77. Fantoni y Benedí, R. de: «Títulos y Grandezas de España concedidos al estamento militar por Carlos II (1665-1700)», en Emblemata, 13 (2007), p. 264. Una breve síntesis sobre la trayectoria profesional posterior del marqués de Pozoblanco se encuentra en Andújar Castillo, F.: Consejo y consejeros de guerra en el siglo XVIII. Granada, 1999, pp. 284-285.

78. SAnz TAPIA, A.: ¿Corrupción o necesidad?..., op. cit., pp. 111-112.

79. La intervención de este agente de negocios aparece bien documentada en el expediente de pruebas para recibir el hábito de caballero de Santiago de Juan de Velasco y Tejada, padre de Francisco Manuel. AHN, Órdenes Militares, exp. 8700. 
hábito de Santiago, Juan de Velasco y Tejada, en enero de 1692, había comprado la futura de gobernador de Buenos Aires por la fortuna de 160.000 reales abonados al contado, pero incluyendo en ese importe la concesión del grado de maestre de campo de los reales ejércitos ${ }^{80}$. Por ende, los caudales de la familia y la relación con las Indias del tío de Francisco Manuel, el general de la flota que arribó a Vigo en 1702, Manuel Velasco Tejada, estuvieron sin duda detrás de la obtención en 1697 del título nobiliario de marqués de Pozoblanco por parte de Francisco Manuel Velasco. De hecho, los 160.000 reales que pagó su padre por el gobierno de Buenos Aires, y que finalmente no ejerció, debieron servirle para conseguir el título nobiliario, pues una cláusula del contrato de compra del cargo establecía que en caso de fallecer antes de ejercerlo dicha cuantía le sería devuelta a sus herederos ${ }^{81}$. Y más aún, el título nobiliario se le concedió a Francisco Manuel «por los méritos de su padre» ${ }^{82}$, que bien pudieron ser la compensación al desembolso hecho por el gobierno de Buenos Aires.

Por otro lado, a Francisco Manuel Velasco tampoco le faltaba experiencia en la formación de un regimiento de nueva leva, pues había vivido en primera persona el proceso de creación del regimiento de caballería de Sevilla -el conocido como «Viejo de Sevilla»- con que había servido la ciudad en el año de 1702, apenas dos años antes de que se decidiese a ascender a coronel mediante la oferta de levantar a su costa un regimiento de caballería ${ }^{83}$. Su primer servicio en el ejército había sido el de capitán de infantería en $1692^{84}$, por tanto, con motivo de la formación de una nueva unidad, y en 1702, cambió al arma de caballería al ser «designado» por la ciudad de Sevilla como capitán del regimiento con que ofreció servir a Felipe V en aquel crítico año de la Guerra de Sucesión. Mediante el nuevo servicio que hizo en 1704 de levantar el regimiento, obtuvo el grado de coronel de los reales ejércitos, un rango que le permitiría situarse en el umbral del generalato en enero de 1707 cuando fue promovido a brigadier, fecha a partir de la cual tendría una exitosa carrera hasta alcanzar los más altos grados del generalato.

80. Archivo General de Indias [en adelante AGI], Contaduría, leg. 156. Sin embargo no llegó a ejercer el gobierno de Buenos Aires porque falleció antes de que vacase. Años después, su hermano, Manuel Velasco Tejada, el general que mandaba la flota que arribó a Vigo en 1702, acabaría sirviendo el citado gobierno por haberlo beneficiado -comprado- por un importe de 180.000 reales. AGI, Indiferente General, leg. 710.

81. AGI, Charcas, leg. 420, L. 10, fols. 11 r. -12 r.

82. Archivo del Ministerio de Justicia, caja 22, exp. 152.

83. El proceso de la creación del regimiento con que sirvió la ciudad hispalense se conoce bien merced a los estudios de Hernández Navarro y Gutiérrez Núñez, F. J.: «Orígenes y primera evolución de los Regimientos de caballería de Sevilla durante la Guerra de Sucesión (1702-1707)», Revista de Historia Militar, 97 (2005), pp. 9-49; «La formación de los regimientos de caballería en Sevilla durante la guerra de sucesión (1702-1707) y prosopografía de sus oficiales», Archivo Hispalense, 259-260 (2002), pp. 41-82.

84. AGS, GM, Expedientes Personales, leg. 43, exp. 24. 
Pero tan interesante como el proceso de formación del denominado regimiento de Pozoblanco resulta constatar cómo aquella empresa sirvió de espacio de aprendizaje para la creación de nuevas unidades en los años siguientes. Del mismo modo que en 1704 Francisco Manuel Velasco ya acumulaba experiencia en la creación de cuerpos de ejército, en su regimiento se forjaron «nuevos levantadores», esto es, individuos que, al igual que Velasco, ingresaron en el ejército adquiriendo sus empleos en las nuevas levas y que luego se aventuraron a iniciar proyectos de formación de regimientos muy similares al que habían conocido personalmente junto al marqués de Pozoblanco. Durante los primeros años de vida del regimiento entraron a servir en el mismo algunos personajes que pocos años después iban a acometer una empresa similar a la de Francisco Manuel Velasco.

Sin duda, el más avezado de todos ellos fue Jaime Miguel Dávalos, II marqués de la Mina, quien acabaría siendo una de las figuras militares más relevantes de la primera mitad del siglo xviII. En su persona convergían, al igual que en la del marqués de Pozoblanco, los dos factores necesarios, riqueza y experiencia previa, para decidirse a formalizar un asiento con el rey para formar un regimiento de nueva leva. La enorme fortuna acumulada por su padre en oscuros negocios en América ${ }^{85}$, y su experiencia en el regimiento de Francisco Manuel Velasco, a donde llegó hacia $1706^{86}$, cuando tan solo contaba con 16 años de edad, posibilitaron que en 1709 levantara a su costa mediante un nuevo asiento un regimiento de dragones con la denominación de Pezuela -nombre que aludía al título de conde de Pezuela de las Torres que ostentaba por entonces- que en 1718 pasaría a ser nombrado como regimiento de Lusitania, y que le permitió alcanzar el grado de coronel con una corta vida militar -tres años de servicio- y una edad de 19 años ${ }^{87}$.

En el mismo regimiento que formó el marqués de Pozoblanco aprendió los caminos de los asientos y del progreso meteórico en el escalafón el jerezano Bartolomé Francisco Ramos, quien de soldado aventurero en 1699 ascendió a capitán de infantería del regimiento que levantó su paisano, Miguel Pavón, a finales de $1703^{88}$. Allí debió aprender las «artes de los asientos» y en septiembre de 1706 cambió de arma al ingresar en el regimiento del marqués de Pozoblanco. Tal cúmulo de experiencias en unidades de nueva leva le permitió lanzarse a esa aventura «empresarial» que siempre significaba la creación de un regimiento y en 1719 «levantó a su costa», esto es, financió la formación del regimiento de dragones de Jerez ${ }^{89}$.

85. Cartaya Baños, J.: Para ejercitar la maestría de los caballos. La nobleza sevillana y la fundación de la Real Maestranza de Caballería en 1670. Sevilla, 2012, pp. 207-224.

86. AGS, GM, leg. 2480, C. II.

87. AGS, GM, Suplemento, leg. 125.

88. AGS, GM, leg. 2475, C. XI.

89. AGS, GM, Suplemento, leg. 30. 
Por último, en el mismo regimiento del marqués de Pozoblanco y siguiendo una trayectoria prácticamente idéntica a la de Bartolomé Francisco Ramos sirvió el sevillano -natural de Constantina- Diego Ponce de León, quien había ingresado en el ejército en octubre de 1702 como capitán, es decir, contribuyendo con hombres o dinero, en el regimiento de Vicentelo. Cuando el marqués de Pozoblanco decidió levantar su regimiento en 1704, Diego Ponce de León levantó a su costa una compañía de caballería, «microasiento» que le permitió cambiar de arma, lo que en la práctica suponía una suerte de ascenso en el escalafón ${ }^{90}$. Tan sólida experiencia en la formación de dos regimientos de nueva leva le condujeron en 1719 a acometer una nueva empresa mediante la firma de un asiento para la formación a su costa del regimiento de dragones de Llerena que le reportó el rango de coronel de los reales ejércitos ${ }^{91}$.

Por tanto, en los casos expuestos, se constata cómo nuevos asientos comportaban siempre ascensos en el escalafón. Era el premio que el rey reservaba a quienes se ofrecían a servirle con unidades de ejército en poco tiempo y sin coste alguno -en todo caso los mínimos- para la real hacienda. El sistema comportaba, tanto por la vía directa como por la indirecta, la venalidad de los empleos de la oficialidad. Era la única contrapartida «negativa» a un sistema eficaz, por cuanto en poco tiempo y sin gasto para las arcas reales, se podía disponer para la guerra de nuevos cuerpos de ejército. Siempre, a lo largo de todo el siglo xviII, la privatización del reclutamiento que comportaba el sistema de asientos para la formación de cuerpos de nueva leva fue el método más efectivo para la obtención de soldados en tiempos de guerra. Luego, llegada la paz, se volvería a los métodos tradicionales de recluta para completar los cuerpos existentes y, para los erigidos con motivo de una contienda bélica, retornaría la eterna incertidumbre sobre el futuro que les aguardaba, pues una parte importante de los regimientos que se levantaban para una guerra se solía desmovilizar tras el final de la misma. Más allá del miedo a perder la vida en la guerra, el temor a la «reforma», esto es a la supresión de regimientos, siempre sería la principal contrapartida para quienes decidieron acometer estas empresas de formación de nuevos cuerpos de ejército que les proporcionaron ascensos en el escalafón, un empleo al servicio del rey y el enorme prestigio social de los empleos adquiridos. No en vano, esas recompensas sociales, en un siglo en el que los salarios de los militares permanecieron prácticamente inalterables, justifican que los asientos para la formación de nuevos cuerpos de ejército contaran siempre con individuos dispuestos a suministrar el número de soldados requeridos para conseguir un empleo de oficial o el dinero que el asentista hubiese estipulado.

90. AGS, GM, leg. 2474, C. V y leg. 2687. C. XIII.

91. AGS, GM, Suplemento, leg. 30. 


\section{Bibliografía}

Andújar Castillo, F.: Consejo y consejeros de guerra en el siglo XVIII. Granada, 1999.

—: «La privatización del reclutamiento en el siglo xviII: el sistema de asientos», en Studia Histórica. Historia Moderna, 25 (2003), pp. 123-147.

-: El sonido del dinero. Monarquía, ejército y venalidad en la España del siglo XVIII. Madrid, 2004.

—: «Empresarios de la guerra y asentistas de soldados en el siglo xviI», en García Hernán, E. y Mafri, D. (eds.): Guerra y sociedad en la Monarquía Hispánica: Política, Estrategia y Cultura en la Europa Moderna (1500-1700). T. II, Madrid, 2006, pp. 375-394.

—: Necesidad y venalidad, España en Indias, 1704-1711. Madrid, 2008.

—: «Milicia y nobleza. Reformulación de una relación a partir del caso granadino (siglos XVII-XVIII)», en JimÉnez Estrella, A. y AndúJar CAstillo, F. (eds.): Los nervios de la guerra. Estudios sociales sobre el ejército de la monarquía hispánica (s. XVI-XVIII): nuevas perspectivas. Granada, 2007, pp. 251-276.

—: «Entre la Corte y la guerra. Militares italianos al servicio de España en el siglo XviII», Guerra e Pace in etá Moderna. Annali di Storia militare europea, 1 (2008), pp. 105-134.

- : «Venalidad de oficios y honores. Metodología de investigación», en StumpF, R. y Chaturvedula, N. (eds.): Cargos e ofícios nas monarquias ibéricas: provimento, controlo e venalidade (séculos XVII-XVIII). Lisboa, 2012, pp. 175-197.

— : «Los contratos de venta de empleos en la España del Antiguo Régimen», en ANDÚJAR Castillo, F. y Felices de la Fuente, $\mathrm{M}^{a} \mathrm{M}$. (eds.): El poder del dinero. Venta de cargos y honores en la España del Antiguo Régimen. Madrid, 2011, pp. 63-82.

BorReguero Beltrán, C.: El reclutamiento militar por quintas en la España del siglo XVIII. Orígenes del servicio militar obligatorio. Valladolid, 1989.

Cartaya Baños, J.: Para ejercitar la maestría de los caballos. La nobleza sevillana y la fundación de la Real Maestranza de Caballería en 1670. Sevilla, 2012.

Colomo García, V.:, «Navarra y la defensa de la monarquía en los reinados de Felipe III y Felipe IV (1598-1665)», Príncipe de Viana, 104 (1995), pp. 163-182.

Eiras Roel, A.: «Las ciudades gallegas ante el cambio dinástico. De las Juntas del Reino seiscentistas a las reformas de Nueva Planta» en Fernández Cortizo, C., Migués Rodríguez, V. M. y Presedo Garazo, A. (eds.): El mundo urbano en el Siglo de la Ilustración. T. I, Santiago de Compostela, 2009, pp. 15-50.

Espino López, A.: «El esfuerzo de guerra de la Corona de Aragón durante el reinado de Carlos II, 1665-1700. Los servicios de tropas», Revista de Historia Moderna. Anales de la Universidad de Alicante, 22 (2004), pp. 209-250.

- : «Recluta de tropas y bandolerismo durante el reinado de Carlos II: el caso de la compañía ilicitana del capitán Gaspar Irles», Revista de historia moderna: Anales de la Universidad de Alicante, 24 (2006), pp. 487-512.

- : «El esfuerzo de guerra de la Corona de Aragón durante el reinado de Carlos II, 1665-1700», Revista de Historia Moderna. Anales de la Universidad de Alicante, 22 (2004), pp. 209-250. 
FANTONi y Benedí, R. de: «Títulos y Grandezas de España concedidos al estamento militar por Carlos II (1665-1700)», Emblemata, 13 (2007), pp. 257-270.

Felices de la Fuente, M M.: La nueva nobleza titulada de España y América en el siglo XVIII (1701-1746). Almería, 2012.

- : «Venta y beneficio de cargos en la España Moderna: consideraciones en torno al concepto de venalidad», en Stumpf, R. y Chaturvedula, N. (eds.): Cargos e ofícios nas monarquias ibéricas: provimento, controlo e venalidade (séculos XVII-XVIII). Lisboa, 2012, pp. 199-211.

Francisco Olmos, J. Ma de: Los miembros del Consejo de Hacienda en el siglo XVII, Madrid, 1999.

Glesener, T.: «La estatalización del reclutamiento de soldados extranjeros en el siglo XVIII», en Reyes García-Hurtado, M. (coord.): Soldados de la Ilustración: el ejército español en el siglo XVIII. A Coruña, 2012, pp. 237-262.

— : «Venalidad y fidelidad en los Países Bajos durante el reinado de Felipe V», en Andújar Castillo, F. y Felices de la Fuente, Ma M. (eds.): El poder del dinero. Venta de cargos y bonores en la España del Antiguo Régimen. Madrid, 2011, pp. 191-209.

Hernández Navarro y Gutiérrez NúÑez, F. J.: «Orígenes y primera evolución de los Regimientos de caballería de Sevilla durante la Guerra de Sucesión (1702-1707)», Revista de Historia Militar, 97 (2005), pp. 9-49.

— : «La formación de los regimientos de caballería en Sevilla durante la guerra de sucesión (1702-1707) y prosopografía de sus oficiales», Archivo Hispalense, 259-260 (2002), pp. 41-82.

Jiménez Estrella, A.: «El reclutamiento en la primera mitad del siglo Xvir y sus posibilidades venales», en Andújar Castillo, F. y Felices de la Fuente, Ma M. (eds.): El poder del dinero. Venta de cargos y honores en la España del Antiguo Régimen. Madrid, 2011, pp. 169-190.

- : «Servir al rey, recibir mercedes: asentistas militares y reclutadores portugueses al servicio de Felipe IV antes de la Guerra de Restauración», en STUMPF, R. y ChatuRvedula, N. (eds.): Cargos e ofícios nas monarquias ibéricas: provimento, controlo e venalidade (séculos XVII-XVIII). Lisboa, 2012, pp. 239-266.

Jiménez Moreno, A.: «Honores a cambio de soldados, la concesión de hábitos de las Órdenes Militares en una coyuntura crítica: la Junta de Hábitos (1635-1642)», en Soria Mesa, E. y Delgado Barrado, J. M. (eds.): Las élites en la época moderna: la monarquía española, Economía y poder. T. III, Córdoba, 2009, pp. 155-171.

López DíAz, Mª «Oligarquías urbanas y milicia: apuntes sobre una relación beneficiosa a partir del caso de Ourense (siglo XvinI)», en Cuadernos de historia moderna, 34 (2009), pp. 95-123.

Martínez Arce, Ma D.: Navarra y el ejército en el conflictivo siglo XVII, Pamplona, 2002. Martínez Ruiz, E.: Los soldados del Rey. Los ejércitos de la Monarquía Hispánica (14801700). Madrid, 2008.

Ostolaza Elizondo, Ma I.: Gobierno y administración de Navarra bajo los Austrias. Siglos XVI-XVIII. Pamplona, 1999. 
PÉrez Estévez, Ma R.: El problema de los vagos en la España del siglo XVIII. Madrid, 1976.

Puell de la Villa, F.: «La ordenanza del reemplazo anual de 1770», Hispania, 189 (1995), pp. 205-228.

Riвот, L.: «Types of Armies: Early Modern Spain», en Contamine, Ph. (coord.): War and competition between States. Oxford, 2000, pp. 37-68.

Rodríguez Hernández, A. J.: Los Tambores de Marte. El Reclutamiento en Castilla durante la segunda mitad del siglo XVII (1648-1700). Valladolid, 2011.

- : «De Galicia a Flandes: reclutamientos y servicio de soldados gallegos en el ejército de Flandes (1648-1700)», Obradoiro de historia moderna, 16 (2007), pp. 213-251.

— .: «La contribución militar del Reino de Granada durante la segunda mitad del siglo xvir: la formación de Tercios de Granada», en Jiménez Estrella, A., Andújar Castillo, F. (eds.): Los nervios de la guerra. Estudios sociales sobre el ejército de la Monarquía Hispánica (Siglos XVI-XVIII): nuevas perspectivas. Granada, 2007, pp. 149-189.

— : «Factores para un reclutamiento a larga distancia: las levas canarias a Flandes y otros destinos a lo largo de la segunda mitad del siglo Xviı», Revista de historia canaria, 189 (2007), pp. 103-132.

- : «Poner una pica vallisoletana en Flandes: reclutamiento y costes del transporte de tropas a los Paises Bajos (1665-1700)», Investigaciones históricas: Época moderna y contemporánea, 28 (2008), pp. 55-78.

- : «Patentes por soldados. Reclutamiento y venalidad en el ejército durante la segunda mitad del siglo XviI», Chronica Nova, 33 (2007), pp. 37-56.

- : «Servir al rey con hombres. Recompensas concedidas a élites y representantes del rey por su colaboración en el reclutamiento (1613-1700)», en EsTEBAn EstrínganA, A. (ed.): Servir al rey en la Monarquía de los Austrias: Medios, fines y logros del servicio al soberano en los siglos XVI y XVII. Madrid, 2012, pp. 415-443.

- : «Los servicios de la nobleza y el reclutamiento señorial en Andalucía durante la segunda mitad del siglo xviı», en Andújar Castillo, F., Díaz López, J. P. (eds.): Los señoríos en la Andalucía Moderna. El Marquesado de los Vélez. Almería, 2007, pp. 639-654.

— : «La venta de títulos nobiliarios a través de la financiación de nuevas unidades militares durante el siglo xviı», Andújar Castillo, F. y Felices de la Fuente, Ma M. (eds.): El poder del dinero. Venta de cargos y honores en la España del Antiguo Régimen. Madrid, 2011, pp. 274-300.

SaAvedra VÁzquez, Ma C.: «Tradición y novedad ante la guerra. Las Juntas del Reino de Galicia en la Guerra de Sucesión», en Bravo Caro, J. J. y Villas Tinoco, S. (eds.): Tradición versus innovación en la España Moderna. T. II, Málaga, 2009, pp. 1133-1150.

—-: «La elite militar del Reino de Galicia durante la Guerra de Sucesión», en López DíAz, Ma (ed.): Elites y poder en las monarquías ibéricas. Del siglo XVII al primer liberalismo. Madrid, 2013, pp. 223-244.

Sanz Camañes, P.: Política, hacienda y milicia en el Aragón de los últimos Austrias, 16401680. Zaragoza, 1997.

SAnZ TAPIA, A.: ¿Corrupción o necesidad? La venta de cargos de gobierno americanos bajo Carlos II (1674-1700). Madrid, 2009. 